\title{
Evaluation of urinary proteins in healty full-term neonates by SDS-PAGE
}

\author{
Snezhana Palchevska ${ }^{1}$, Velibor Tasik ${ }^{1}$, Petar Korneti², \\ Georgi Shestakov², Svetlana Tsekovska² \\ ${ }^{1}$ Clinic for Children Diseases, Faculty of Medicine, Vodnjanska 17, Skopje, Republic of Macedonia \\ ${ }^{2}$ Insitute of Medical and Experimental Biochemistry, Faculty of Medicine, 50 Divizija 6, Skopje, Republic of Macedonia
}

Received April 2004, accepted June 2004

\begin{abstract}
The pattern of urinary proteins in healthy full-term neonates was examined by sodium dodecyl sulfate polyacrylamide gel electrophoresis (SDS-PAGE), coupled with determination of few parameters related to urinary protein excretion.

Twenty healthy full-term neonates were included in the investigation. Five urine samples from each subject were collected on days 3, 7, 14, 21 and 28 after birth. Determination of total proteins was performed using turbidimetric method with sulfosalicylic acid. Urinary creatinine concentration was determined by Jaffe method. Urinary proteins were separated by horizontal gradient SDS-PAGE according to Görg.

The highest values for total urinary proteins and for protein/creatinine ratio were detected in urine samples excreted on days 3 and 7 after birth. Three types of SDS-PAG electrophoretic profiles were observed. The first type of electrophoretic profile was characterized by the presence of proteins of mixed glomerular and tubular origin with molecular weights from 10 to $160 \mathrm{kDa}$. Typical for the second type of electrophoretic profile was the presence of two faint fractions with molecular weights of 78 and $90 \mathrm{kDa}$ and several intensive low molecular weight fractions (14-67 kDa). In the third type of electrophoretic profile only low molecular weight proteins (10-67 kDa) were detected in all five urine samples. These findings express the transitory immaturity of the glomerular filter and tubular protein reabsorbing system of the newborn kidney. Apparently, the tubular protein handling normalizes later than the glomerular filtration of proteins.
\end{abstract}

Key words: Proteinuria; neonates; SDS-PAGE; electrophoretic profiles

\section{Introduction}

It has been clearly demonstrated that the renal cells are not fully differentiated at birth and that many of the differences in renal function seen between infants and adults should be attributed to immaturity (1). This renal immaturity does not seem to carry any risk in healthy full-term infants fed an appropriate diet, but can represent a major risk in situation of disease, inappropriate fluid and electrolyte losses, and exogenous pharmacologic stress (2).

Renal insufficiency and renal failure of newborns in an intensive care unit is a very common problem. It was reported that between 8 and $24 \%$ of neonates in special care wards ex-

Snezhana Palchevska

e-mail:zanpal@hotmail.com

tel. +389 2 3147-717; fax. +389 2 3230-43 perience renal failure (3). Acute renal failure is a recognized complication of birth asphyxia and may result in permanent renal damage in up to $40 \%$ of survivors (4).

Taking all these facts into account it is obvious that evaluation of renal glomerular and tubular functional and structural integrity in neonates is of great importance. For this purpose in clinical practice the investigation of a battery of biochemical parameters is frequently undertaken.

Measuring of serum concentration of creatinine, as well as cistatin $\mathrm{C}$ is frequently used as a parameters for evaluation of glomerular function (5). A more precise assessment of the functional capacity of the kidney is made by measuring glomerular filtration rate (GFR), but this procedure is expensive, time consuming and invasive because puncture of peripheral vein is necessary to obtain several blood samples $(6,7)$. 
It is generally recognized that urine, as a medium, is a source of great number of diagnostic information. Determination of concentration of total urinary proteins, as well as measuring of concentration of different urinary proteins has been used to monitor kidney and urinary tract disease for more than 150 years. The determination of total urinary protein does not differentiate between glomerular and tubular proteinuria. It has been demonstrated that different urinary proteins carry different diagnostic information (8). So, urinary concentration of high-molecular proteins, especially albumin and immunoglobulin $\mathrm{G}$, are the best markers for assessment of glomerular function. Determination of urinary concentration of low-molecular weight proteins, such as $\alpha_{1}$-microglobulin, $\beta_{2}$-microglobulin and retinol binding protein (RBP) is recommended as potential markers for evaluating function of renal proximal tubules (9). Measuring of fractionary excretion of urinary sodium is used for investigation the functional reabsorption capacity of the distal segment of the nephron. Of all urinary enzymes, the brush-border membrane enzyme leucine-aminopeptidase (LAP) and the lysosomal N-acethyl- $\beta$-D-glucosaminidase (NAG) were recommended as markers for investigation of the structural integrity of renal proximal tubules (10).

In the recent years the accent is put on separation of urinary proteins using high resolution electrophoretic techniques, such as sodium dodecyl sulfate-polyacrylamide gel electrophoresis (SDS-PAGE), capillary electrophoresis and 2D-electrophoresis (11).

The results from great number of studies have shown that SDS-PAGE is a method of choice for detection of early renal lesions (12). It is also very attractive method, because of its non-invasive nature, relatively low price and accuracy.

In the present work the patterns of urinary proteins in healthy full-term infants during the first month of life were investigated by SDS-PAGE, coupled with determination of few parameters related to urinary protein excretion.

The purpose of this examination is to evaluate SDSPAGE profiles characteristic for healthy newborn infants; this is the basis for further evaluation of SDS-PAGE in assessment of glomerular and tubular function in conditions in which renal function might be affected (such as hypoxic ischemic encephalopathy, sepsis, nephrotoxic agents etc.).

\section{Experimental}

The present investigation was conducted on 20 healthy full-term neonates with gestational ages ranging from 36 to 41 weeks (mean $38.2 \pm 1.10$ weeks).

Urinary samples excreted on day 3,7,14,21 and 28 after birth were used for all examinations. Collection of urine samples was made by using a collection bag placed over the infants' external genitals. All samples were taken promptly to the laboratory and centrifuged on $3000 \mathrm{rpm}$ for 15 minutes.

Total urinary proteins were determined by the Meuleman`s method, using sulfosalicylic acid (13). Urinary creatinine concentration was determined by Jaffe method (14). Proteine/creatinine ratio $(\mathrm{P} / \mathrm{C})$ was calculated by dividing the total urinary protein concentration with urinary concentration of creatinine.

Separation of urinary proteins was performed by horizontal ultrathin pore gradient-dodecyl sulfate electrophoresis according to Görg et al. (15). Urinary samples were neither diluted nor concentrated; $0.9 \mathrm{ml}$ urine with $0.1 \mathrm{ml}$ sample buffer (1.5 M Tris/HCl, $10 \%$ SDS, $\mathrm{pH}$ 8.8) was incubated for 3 minutes in boiling water. SDS-polyacrylamide gradient gels (4-22 \%) were prepared by standard procedure in dimensions 195 x 250 x $0.5 \mathrm{~mm}$. SDS-PAGE worked at $5^{\circ} \mathrm{C}$ for 2 hours on Multiphor II Unit, LKB (Brown, Sweden). Pharmacia LKB low-molecular weight calibration proteins were used for determination of molecular mass of separated protein fractions. Gels were stained with Coomassie Blue R250 and prepared in stable preparations.

\section{Results and discussion}

Results regarding the concentration of total urinary proteins and $\mathrm{P} / \mathrm{C}$ ratio in healthy full-term neonates on days 3,7,14,21 and 28 of life are presented in Table 1.

The highest values for total urinary proteins in healthy full-term neonates were detected in urinary samples excreted on days 3 and 7 after birth with upper value of $405 \mathrm{mg} / \mathrm{L}$ and lowest values in samples excreted on days 21 and 28 of life with range between 10-50 mg/L.

The highest detected value for $\mathrm{P} / \mathrm{C}$ ratio was detected in urinary samples excreted on day 3 of life (480 mg/g cre-

Table 1. Data (arithmetic mean and range) for total urinary proteins and P/C ratio on days 3,7,14,21 and 28 after birth in healthy full-term neonates $(\mathrm{n}=20)$

Healthy full-term neonates

\begin{tabular}{|c|c|c|c|c|c|}
\hline Parameters & Day 3 & Day 7 & Day 14 & Day 21 & Day 28 \\
\hline Total urinary proteins & 156 & 130 & 32 & 29 & 25 \\
\hline$(\mathrm{mg} / \mathrm{L})$ & $(10-405)$ & $(10-355)$ & $(10-120)$ & $(10-50)$ & $(10-50)$ \\
\hline $\mathrm{P} / \mathrm{C}$ ratio & 190 & 297 & 139 & 153 & 134 \\
\hline (mg/g Creatinine) & $(30-480)$ & $(38-460)$ & $(30-415)$ & $(80-248)$ & $(36-369)$ \\
\hline
\end{tabular}


atinine). The highest mean arithmetic value for $\mathrm{P} / \mathrm{C}$ ratio was detected in urine samples excreted on day 7 after birth (297 mg/g creatinine). The differences in arithmetic means for $\mathrm{P} / \mathrm{C}$ ratio between day 3 and day 28 were not so expressive like for the total urinary proteins concentration.

Fig.1, 2 and 3 present typical SDS-PAGE profiles obtained from separation of urinary proteins in neonates, included in conducted investigation. For electrophoretic separation of each subject, five different urinary samples (excreted on day 3,7,14,21 and 28 of life), with laterally applicated protein markers, were used.

In $40 \%$ of neonates $(\mathrm{n}=8)$ electrophoretic profiles were characterized by the presence of proteins of mixed glomerular and tubular origin, detected in all five urinary samples. The molecular weight of proteins were found to be distributed over a wide range from 10 to $160 \mathrm{kDa}$. The intensity of fractions was highest in urine sample excreted on days 3 and 7 and decreased thereafter. On day 3 the fractions with highest intensity were those with molecular weight of $67 \mathrm{kDa}$ (albumin) and molecular weight of about $30 \mathrm{kDa}$. One week after birth the low molecular weight proteins predominated because there was a substantial decrease in the excretion of albumin and of high molecular weight proteins (Fig. 1).

In $20 \%$ of neonates electrophoretic profiles were characterized with presence of two faint fractions with molecular weights of about $78 \mathrm{kDa}$ and $90 \mathrm{kDa}$, and several intensive and higher proportional low molecular weight fractions (from 14 to $67 \mathrm{kDa}$ ). Fractions with molecular weight of about $45 \mathrm{kDa}, 30 \mathrm{kDa}$ and $14 \mathrm{kDa}$ were the most prominent in urinary samples excreted on days 3 and 7 after birth. The intensity of all fractions decreased in urinary samples excreted on days 14, 21 and 28 after birth (Fig. 2).

In other $40 \%(n=8)$ of newborns in all urinary samples only the presence of low molecular weight proteins (from 10$67 \mathrm{kDa}$ ) was detected. The intensity of fractions was highest in urinary samples excreted on days 3 and 7 after birth and lowest in samples excreted on days 21 and 28 of life. In 7 of neonates with this type of electrophoretic profile in samples excreted 21 and 28 days after birth, the presence of only albumin fraction was detected (Fig. 3).

Physiological proteinuria in adults is well known with many studies regarding the determination of physiological excretion of different proteins as well as separation of urinary proteins with SDS-PAGE $(16,17,18)$. There are also a great number of studies related to quantitative changes in some specific urinary proteins during the first month of life and later in early infancy and older children $(19,20)$. There are only a few reports in literature regarding the SDS-PAGE electrophoretic profiles in healthy newborns (21-23).

In view of the lack of knowledge about physiological proteinuria in neonates, the present study was undertaken to

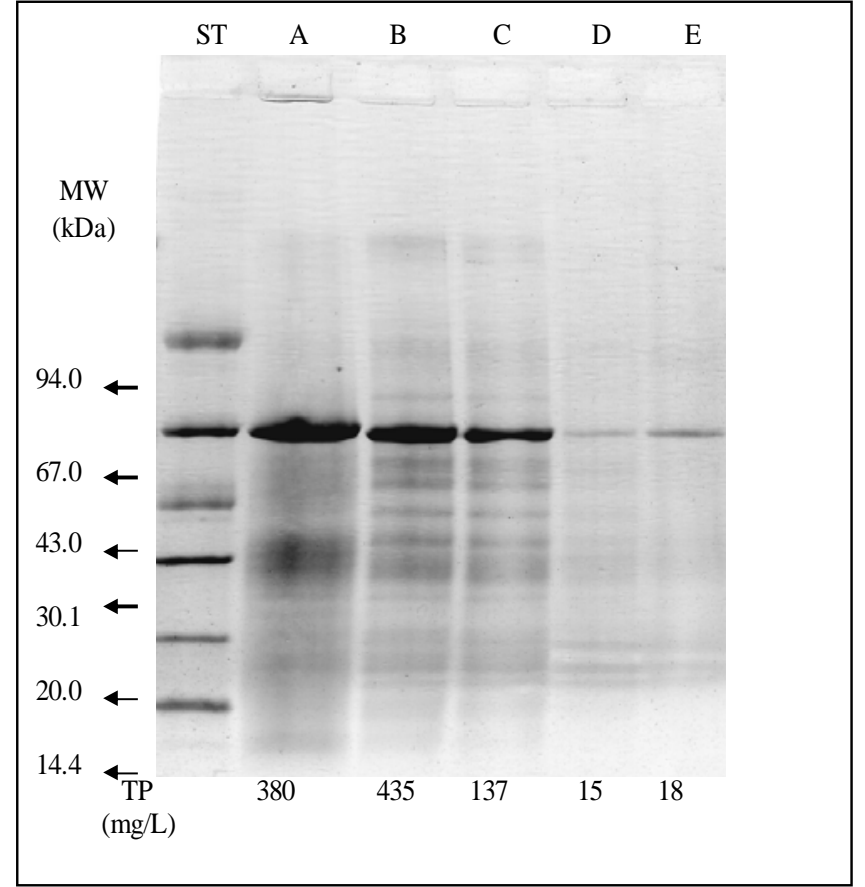

Fig. 1 Electrophoretic profiles of urinary proteins in healthy full-term neonate $3,7,14,21$ and 28 days after birth (A,B,C,D,E)

TP: total urinary proteins in mg/L, MW: molecular weight, ST: Standard (Pharmacia LKB LMW calibration proteins)

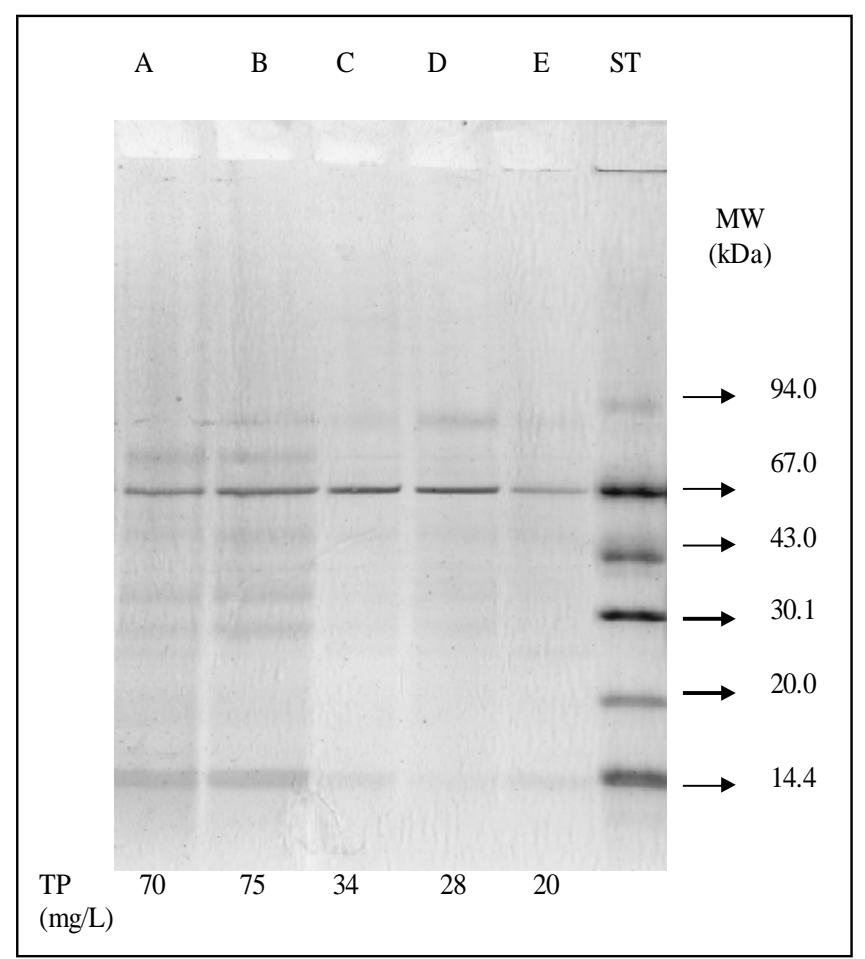

Fig. 2 Electrophoretic profiles of urinary proteins in healthy full-term neonate 3, 7, 14, 21 and 28 days after birth (A,B,C,D,E)

TP: total urinary proteins in mg/L, MW: molecular weight, ST: Standard (Pharmacia LKB LMW calibration proteins) 


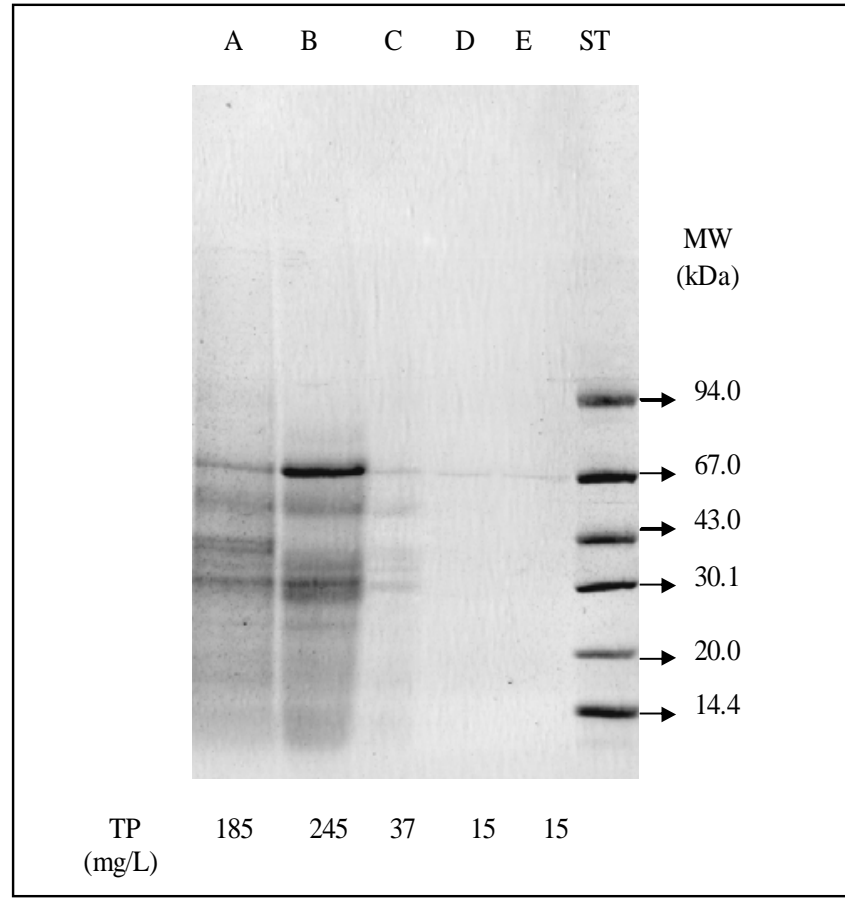

Fig. 3 Electrophoretic profiles of urinary proteins in healthy full-term neonate

3, 7, 14, 21 and 28 days after birth (A,B,C,D,E)

TP: total urinary proteins in $\mathrm{mg} / \mathrm{L}$,

MW: molecular weight,

ST:Standard (Pharmacia LKB LMW calibration proteins)

obtain more information about the quantity and SDS-PAGE profiles in these subjects.

The results obtained in our study for total urinary concentration have shown the highest values for TP excretion detected on days 3 and 7 with range from 10-405 mg/L which decrease thereafter with range from $10-50 \mathrm{mg} / \mathrm{L}$ on days 21 and 28. There are only a few reports related to TP concentration in neonates with different methods used for TP determination. The results in our study was in close agreement with the findings from Miltenyi (22) who reported TP concentration between 95 - $455 \mathrm{mg} / \mathrm{L}$ in healthy full-term newborn infants in the first month of life (7-30 days old).

In our study the determination of proteine-to creatinine ratio was included, since the results of great number of studies of adults and children have shown that there is a strong correlation between the urine $\mathrm{P} / \mathrm{C}$ ratio, obtained in random urine samples, and 24-hour urinary protein excretion corrected for body-surface area (24-26). Thus with determination of $\mathrm{P} / \mathrm{C}$ ratio there is no need for 24 -hour urine collection.

The highest value for $\mathrm{P} / \mathrm{C}$ ratio in our study was detected in urine samples excreted on day 3 after birth $(480 \mathrm{mg} / \mathrm{g}$ creatinine). In urine samples excreted on day 7 a similar values for $\mathrm{P} / \mathrm{C}$ was determined as in samples excreted on day 3. In urinary samples excreted on day 14, 21 and 28 the values for $\mathrm{P} / \mathrm{C}$ ratio were lower with highest detected val- ues of $415 \mathrm{mg} / \mathrm{g}$ creatinine. It is obvious that the differences between values for $\mathrm{P} / \mathrm{C}$ ratios between urinary samples excreted on day 3 and samples excreted on days 7,14, 21 and 28 was no so expressive like the differences noticed for otal protein concentration expressed in $\mathrm{mg} / \mathrm{L}$ for the same urinary samples. In urine samples excreted on day 3 the values for total protein concentration ranged between 10-405 $\mathrm{mg} / \mathrm{L}$ and decreased rapidly thereafter in urine samples excreted on day 14 (10-120 mg/L) with lowest values in samples obtained on days 21 and 28 (10-50 mg/L). These results confirmed the usefulness of urinary $\mathrm{P} / \mathrm{C}$ ratio as a better measure for urinary protein concentration, since it is very obvious that dividing the total protein concentration by urinary creatinine concentration eliminates variations due to changing rates of urine output and provides a measure independent of urine concentration.

The results obtained in our study for $\mathrm{P} / \mathrm{C}$ ratio was in close correlation with the results reported by other investigators. In a study of Houser (26) the upper value for P/C ratio found in 1 month old healthy infants was $500 \mathrm{mg} / \mathrm{g}$ creatinine, which value is very similar to the values in our investigated group of healthy neonates in first month of life.

The SDS-PAGE profiles obtained in our study from investigation of the physiological proteinuria in healthy fullterm neonates reflected an incompletely developed renal function. The presence of numerous bands distributed over the broad range of molecular weights observed in urine samples from neonates could be explained with transitory immaturity of the glomerular filter and of the tubular protein reabsorbing system of the newborn kidney. Apparently, the SDS-PAGE profiles demonstrated that tubular protein handling normalizes later than the glomerular filtration of proteins.

The presence of protein fraction with molecular weight of about $160 \mathrm{kDa}$, which according to molecular weight belonged to imunoglobulin $\mathrm{G}$, in some urinary samples of neonates excreted on days 3 and 7 after birth (Fig. 1), could be due to the fact that maternally derived antibodies are present at birth. Likewise, in the most of neonates prominent fraction with molecular weight of about $45 \mathrm{kDa}$ was detected in urinary samples excreted on days 3 and 7 after birth, which according to molecular weight belonged to $\alpha_{1}$ - acid glycoprotein, probably due to the acute phase response at birth.

Electrophoretic SDS-PAGE profiles, obtained in our study, have shown that the intensity of albumin fraction (67 $\mathrm{kDa}$ ) decreased during the neonatal period, which finding could be supported by the results from quantitative determination of albumin in urine samples of neonates, excreted during the first month of life, reported by Tsukahara et al (27). The results from their study have shown that urinary albumin decreased postnatally in healthy full-term neonates, while it remained almost constant in preterm neonates. In sick pre- 
terms who were depressed at birth and have respiratory failure, urinary albumin was elevated during the first week, indicating the presence of glomerular damage in this period.

In almost all urinary samples excreted on days 3, 7 and 14 after birth, intensive fraction with molecular weight about $30 \mathrm{kDa}$ was detected, which according to molecular weight belonged to $\alpha_{1}$-microglobulin. This findings is in close correlation with the results from quantitative determination of $\alpha_{1}$-microglobulin in urine samples of neonates, reported from Tsukahara et al. (28). The results from their study have shown high levels of $\alpha_{1}$-microglobulin in urine samples of neonates excreted during the first two weeks of life, which declined thereafter. This finding is due to the fact that $\alpha_{1}$-microglobulin was found by many authors to be early marker of renal tubular dysfunction, characterized by incomplete or inadequate reabsorption of low molecular weight proteins.

On SDS-PAGE profiles, obtained in our study, in a great number of urine samples from neonates, excreted on days 3 and 7 , the presence of protein fraction with molecular weight of aproximately $12 \mathrm{kDa}$, with poor resolution, was found (Fig. 1 and Fig. 3). According to molecular weight this fraction belonged to $\beta_{2}$-microglobulin, which finding could be supported by results from quantitative determination of $\beta_{2}$ microglobulin in urine samples of neonates, during the first month of life, reported by Tsukahara et al (27). The results from their study have shown peak level on day 7 for $\beta_{2}$-microglobulin, both in term and preterm neonates, with trend towards higher levels of $\beta_{2}$-microglobulin with decreasing gestation, showing that proximal tubular protein reabsorption decreases with increasing degrees of prematurity. In sick preterms who were depressed at birth and had respiratory failure, this parameter was elevated during the first two weeks, indicating the presence of tubular damage in this period.

Electrophoretic SDS-PAGE profiles in 16 of neonates have shown the presence of visible, but with poor resolution protein fraction, with molecular weight of about $16 \mathrm{kDa}$. This fraction was found in all urine samples excreted on days 3,7 and 14 and in some urine samples excreted on days 21 and 28 as a palide fraction. According to molecular weight this fraction belongs to hemoglobin, which is the fraction considered to be physiological, due to the shortened life of erythrocytes (22).

Karlsson and Kristoffer (21) investigated the urinary protein pattern of pooled urine samples in the first year of life. They found a tubular type proteinuria in a pooled urine sample of eight 1- 4 week old newborns, while the protein pattern of the pooled urine of eight 4-6 month old infants was identical with the pattern of adults. Their study has shown that tubular proteinuria disappears gradually during the first years of life. Miltenye and his coworkers (22) fractionated the urinary samples from 20 full-term neonates (aged from 7 to 30 days) by sodium dodecyl sulphate gel discelectrophoresis $(7.5 \%$ polyacrylamide gels stained with $0.6 \%$ Amido Black in $7 \%$ acetic acid). The results from their study have shown that proteinuria was predominantly tubular, although in some urine samples high molecular weight protein fractions with molecular weight bigger than $100000 \mathrm{kDa}$ was detected, as well as middle molecular weight fractions (89 000 and $80000 \mathrm{kDa}$ ). They reported also the presence of hemoglobinuria during the first weeks of life.

The results obtained by analysis of the molecular weights of urinary proteins in healthy newborns, separated by SDS-PAGE and stained with Coomassie Brilliant Blue G-250, reported by Thanner et al. (23) confirmed the findings of previous mentioned authors for presence of glomerulo-tubular imbalance in early life. According to the number of separated protein fractions and their relative concentration (expressed as percent of total protein concentration) they concluded that proteinuria in healthy full-term neonates is predominantly tubular and is due to ineffective proximal tubular reabsorption of low molecular weight microproteins.

\section{Conclusion}

The results in the present study, related to examination of SDS-PAGE profiles in healthy full-term neonates, confirmed the results obtained by other investigators that electrophoretic profiles are a source of great number of information about the physiological proteinuria frequently detected in urine of neonates by screening methods. Knowledge of the modifications that occur in urinary protein pattern due to age is therefore very important in order to distinguish such modifications from those caused by other factors. Investigation of SDS-PAGE profiles, coupled with determination of few parameters related to protein excretion, such as total urinary protein concentration and proteine-to-creatinine ratio might be of great usefulness for detection of early renal lesions in neonates, in clinical condititions in which renal function is affected.

\section{References}

1. H. Awad, I. El-Safty, M. El-Barbary, S. Imam. Am. J. Med. Sci. 324 (5), 261-266 (2002).

2. M. Vanpee, P. Herin, R. Zetterstrom, et al. Acta. Pediatr. Scand. 77, 191-197 (1998).

3. R. Hentschel, B. Lodige, M. Bulla. Clin. Nephrol. 46, 54-58 (1996).

4. P.A. Jose, R.D. Fildes, R.A. Gomez, et al. Curr. Opin. Pediatr. 6, 172-177 (1994).

5. A. Shimizu-Tokiwa, M. Kobata, H. Io, N. Kobayashi, I. Shou, K. Funabiki, M. Fukui, S. Horikoshi, I. Shirato, K. Saito, Y. Tomino. Nephron. 92, 224-226 (2002). 
6. M.G. Coulthard. J. Pediatr. 102, 923-930 (1983).

7. H. Ekblad, P. Kero, H. Korvenranta. Biol. Neonate. 61, 308-317 (1992).

8. M.H. Weber, R. Verwiebe. Eur. J. Clin. Chem. Clin. Biochem. 30, 683-691 (1992).

9. A. Lun, M. Ivandic, F. Priem, G. Filler, M. Kirschstein, J. H. H. Ehrich, W. G. Guder. Pediatr. Nephrol. 13, 900-906 (1999).

10. A. Bedir, I.C. Ozener, K. Emerk. Nephron 74, 110-113 (1996).

11. T. Marshall and K.M. Williams. Electrophoresis 19, 1752-1770 (1998).

12. M.T. Pires. Nephron. 14 (5), 361-372 (1975).

13. D. Meulemans. Clin. Chim. Acta 5, 757-761 (1961).

14. H. Bartels, M. Bohmer. Clin. Chim. Acta 37, 193-197 (1972).

15. A. Görg, W. Postel, J. Weser, H.W. Schiwara, W.H. Boesken. Science Tools 32(1), 5-9 (1985).

16. A. Cao, L. Balant, J. Fabre, J.C. Canavese. Schweiz. Med. Wochenschr. 105 (14), 421 (1975).

17. H. Kawakami, T. Murakami, T. Kajii. Clin. Nephrol. 33 (5), 232-236 (1990).

18. J.S. Elises, P.D. Griffiths, M.D. Hocking, C.M. Taylor, R.H. White. Clin. Nephrol. 30 (4), 225-229 (1988).
19. H. Yokoyama, Y. Uchigata, T. Otani, M. Tomioka, K. Kodama, Y. Omori. Diabetes. Res. Clin. Pract. 21, 167-170 (1993).

20. A.M. Skinner, G.M. Addison, D.A. Price. Eur. J. Pediatr. 155 (7), 596-602 (1996).

21. F.A. Karlsson and K. Hellsing. J. Pediatr. 89, 89 (1976).

22. M. Miltenyi. Clin. Nephrol. 12 (5), 216-221 (1979).

23. F. Thanner, R. Wartha, D. Gekle. Klin. Wochenschr. 57, 285-291 (1979).

24. A.B. Shaw, P. Risdon, J.D.L. Jackson. British. Med. J. 287, 929-932 (1983).

25. J.Jr. Lemann, B.T. Doumas. Clin. Chem. 33 (2 Pt 1), 297-299 (1987).

26. M. Houser. J. Pediatr. 104, 845-848 (1984).

27. H. Tsukahara, Y. Fujii, S. Tsuchida, M. Hiraoka, K. Morikawa, S. Haruki, M. Sudo. Nephron. 68(2), 212-216 (1994).

28. H. Tsukahara, M. Hiraoka, M. Kuriyama, M. Saito, K. Morikawa, M. Kuroda, T. Tominaga, M. Sudo. Pediatr. Nephrol. 7(2), 199-201 (1993).

\title{
Резиме
}

\section{Евалуација на уринарните протеини кај здрави доносени новородени со примена на SDS-PAGE}

\author{
Снежана Палчевска ${ }^{1}$, Велибор Тасиќ ${ }^{1}$, Петар Корнети ${ }^{2}$, \\ Георги Шестаков ${ }^{2}$, Светлана Цековска \\ ${ }^{1}$ Клиника за яейски болестии, Меяицински факулиеети, Вояњанска 17, 1000 Скойје,

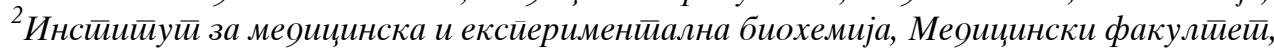 \\ 50 Дивизија бр. 6, Скойје, Рейублика Макеоонија
}

Клучни зборови: Протеинурија, новородени, SDS-PAGE, електрофоретски профили

Извршено е испитување на видот на излачените уринарни протеини кај здрави доносени новородени со примена на натриум додецил сулфат полиакриламид гел електрофореза (SDS-PAGE), заедно со одредување на неколку параметри поврзани со екскрецијата на уринарните протеини.

Во испитувањето беа вклучени 20 здрави доносени новородени деца. Како материјал во испитувањето беа користени по пет примероци урина од секое новородено, излачени $3,7,14,21$ и 28 дена по раѓањето. Определувањето на вкупните протеини беше направено со турбидиметриски метод со сулфосалицилна киселина. Концентрацијата на креатининот во примероците урина беше определувана со методот по Jaffe. Сепарацијата на уринарните протеини беше направена со хоризонталната градиентна SDS-PAGE според Görg.

Највисоки вредности за вкупните уринарни протеини и за протеин/креатинин соодносот беа детектирани во примероците урина излачени третиот и седмиот ден по раѓањето. Беа утврдени три типа на електрофоретски профили. За првиот тип електрофоретски профили беше карактеристично присуството на протеини од мешано, гломеруларно и тубуларно потекло со молекуларна маса од 10 до $160 \mathrm{kDa}$. Типично за вториот тип електрофоретски профили беше присуството на две бледи фракции со молекуларна маса од 78 и $90 \mathrm{kDa}$, како и повеќе интензивни ниско молекуларни фракции (14-67 kDa). За третиот тип електрофоретски профили карактеристично беше присуството само на ниско молекуларни фракции (10-67 kDa) во сите пет испитувани примероци урина. Може да се заклучи дека наодите од испитувањето ја изразуваат минливата незрелост на гломеруларниот филтер и на системот за реапсорбција на тубуларните протеини кај бубрегот од новороденото. Очигледно е дека тубуларната функција се воспоставува подоцна во споредба со гломеруларната филтрација на протеините. 